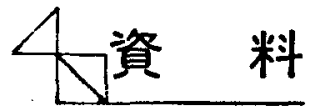

\title{
環境化学計測における電気分析
}

\section{の最近の動 向}

m,

はじめに

環境污染が人類の生存に大きくかかわっている現在， その実態を正確に把握し適切な対策，処置を講ずること が今日的急務々なっている。そのために泣まず，信頼度 が高く, 高感度で, 省力化の谁しだ分析法の確立が必要 となる，加えて，使用する分析法自体が污染源とならな いようなクリーンアナリシスの確立も同時に要求されて くる.

一般的に, 電気化学的方法は, 感度, 精度が高く, 自 動化, 連続化が容易, クローズド化が朾能, 等の諸点に おいて他の分析法よりも高い可能性を有しているが，現 時点では一部の電解法, 電導度法を除いて環境分析に適 用されているものは少ない，そのおもな理由は，他の分 析法にも共通した点ではあるが，安定性，選択性，素子 の污れ，等の諸問題に依るところが大きく，実験牢的手 法とフィールドに㧍ける測定法とのギャップの深さを感 じさせる.

本稿では主として最近の研究の中から, 環境測定法と してすでに利用されているむの，支るいは今後の発展が 期待されるもの等について, ポテンショメトリー,アン ペロメトリー,クーロメトリーに分類して解説する。い くつかの研究では 2 種類以上の原理がうまく組合されて いるものもあるが，本稿ではそれらをより基本的と孝え られる原理に従って分類した. 電気化学的方法の中で電 気伝導度測定法は比較的当初上り環境分析に用いられて いるものの一つであるが，すでに多くの解説，総説で触 れられているので本稿では割愛しだ、また，各法の基

* Louisiana State University in New Orleans

** 東京都立大学工学部工業化学科（東京都世田谷区深沢 2-11)
本原理についてはそれぞれの解説, 総説, あるいは単行 本”る参照していただきたい。

\section{1 ポテンショメトリー}

\section{1 イオン選択性電極}

1960 年代にハンガリーの Pungor によって創始され たイオン選択性電極は，その後急速な発展を遂げ，現 在, 液膜型, 固体膜型等多くの電極が開発されまた市販 されている，広義に法ガラ大電極や酵素電極引などもイ オン選択性電極に含まれると考えられるが，環境測定一 の応用といら見地加らは, 難溶性程应答素子上する固 体膜電極が汎用されている. 使用される電極の種類はき わめて多く, その対象も大気, 水質の両面に渡ってい る.

イオン選択性電極の測定原理, 製法, 取り扱いなどに 関してはすでに多くの総説")や単行本 ${ }^{5}$ 出出されている ので, ここではイオン選抧性電極を検出器として用いる 連続測定法について紹介するにとどめる.

Rủžička $ら^{6)}$ は, Flow Injection Analysis と名ぶけ た連続流れ方式の自動分析計を開発し，その検出部にイ オン選択性電極を用いている. 分析目的に上って全体の 流路系は異なるが，その一例として排水や大気中の硝酸 塩測定に用いた流路系を図 1 に示す7). 装置の主要素 は, 送液ポンプ〜試料注入器〜混合細管〜梌出器上り成 って打り， $\mathrm{pH}$ 楥衝液を一定流速で連続的に流寸。試料 溶液は, 試料注入部より注射器で注入する. 検出器に は，真化テトラオクチルアンモニウムをフタル酸ジブチ ルに溶玑してポ塩化ビニルに埋め込んだイオン選抧性 膜電極を使用しており，図20上うな配置となってい る. 電極をこのように配置することにより, その死容量 


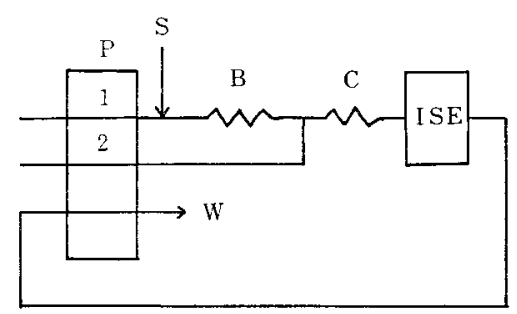

図 1 硝酸塩測定用の流路図 1,2:緩衝液， B，C：混合細管，W:排水 $\mathrm{S}$ : 試料注入口, $\mathrm{P}$ : 送液ポンプ ISE : 检恉器（イオン選択性電極）

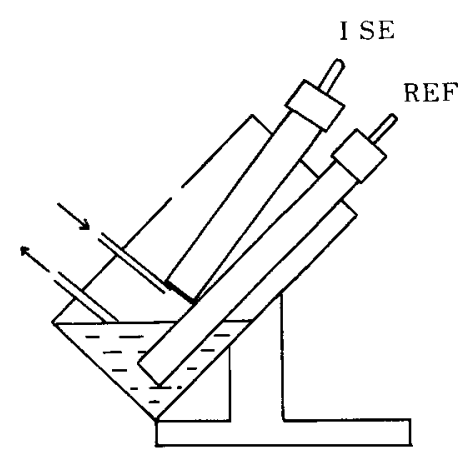

図 2 検出部の電極配置 ISE : イオン選択性䉓極 REF : 参照電栖!

(Dead Volume) をきわめて小さくすることができる． 寸なわち死容量崦電極表面を覆う電解液の薄層部分 ( 5 $\sim 10 \mu l)$ たけとなる.この方法によって, $10^{-2} \sim 10^{-5} \mathrm{M}$ 硝酸塩を $1 \sim 2 \%$ の標準偏差で 1 時間当り 90 検体の割 で分析した，

Mascini" ${ }^{8}$ は，市販のフッ素イオン選択性電極を検出 器とする大気中フッ化水素の自動分析装置を製作した。 この装置では, 試料空気在薄層状の炭酸ナトリウム吸収 液に 1 時間接触吸収させた後, 電極を備えた測定七ル中 一導人する方法をとっている.

最近，䤃素反匛を利用する生物電気化学センサー93(酵 素電極)の開発に法著しいものがあり, 測定対象, 電極 構造も多種に及んでいる(0),11)。この種のセンサーは現 在のところ扔もに臨床分析に限られているが，電極のも つ反応の特異性在考慮すると，今㣪環境分析心の态用加 望まれるものの一つである。

\section{2 固体電解質電極}

固体電解質を用い万電気化学的測定法注近年特に著し い進歩を遂げているが，環境分析に適用されているもの は大して多くない，それは連続測定の立場から見れば， 素子の污染, 寿命, さらに選択性等の諸問題が解決して
いないためと思われる、一方, 酸化ジルコニウムを素子 とする酸素濃度計は，この種の測定法としては現在比較 的多用されている。この方法では, 酸化ジルコニウムの 雨面に電極を設け, 片面に参照用酸素ガス, 他面に酸素 を含む試料ガスを通じて，両極間の電位差を測定し酸素 濃度（分圧）を決定する。この電位差はネルンストの式 より次のように表わされる。

$$
E=\frac{R T}{4 F} \ln \frac{P_{\mathrm{O}_{2}}{ }^{\prime \prime}}{P_{\mathrm{O}_{2}}{ }^{\prime}}
$$

ここで, $R$ はガス定数，Tは絶対温度，Fはファラデ 一定数, $P_{\mathrm{O}_{2}}{ }^{\prime \prime}$ は参照酸素ガスの分圧であり, したがっ て試料ガス中の酸素分压 $P_{\mathrm{O}_{2}{ }^{\prime}}{ }^{\prime}$ 分決定できる.

最近, Haaland ${ }^{122}$ は, この酸化ジルコニウム(さらに 酸化イットリウムもしくは酸化カルシウムを少量含む) 素子を 2 個組合せた 2 セル型酸素濃度計を開発した。一 方は従来の測定せルであり，他方は測定セルで生じた電 位差がゼロになる*1 交で参照用酸素ガスを電気化学的 に生じさせる (pumping) ためのセル(ファラデーセル) である.この酸素計では, pumpingして測定セルの電位 差がゼロになるまでに要したファラデーセルの電流の積 分值より酸素濃度を求める。この点, 従来の酸化ジルコ ニウム酸素濃度䛅と若于異なり，ポテンショメトリーと は言い難いかも知孔ない。の装置の測定系赵 3 に示

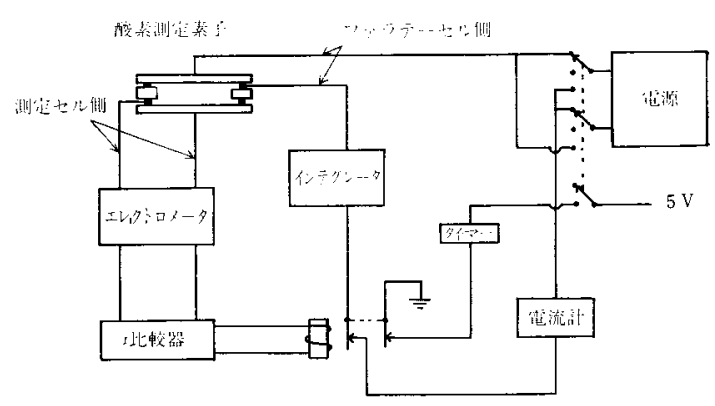

図 3 酸素濃度計

した，その他，硫酸カリウムを固体電解質とした， ppm オーダーの $\mathrm{SO}_{2}, \mathrm{CO}, \mathrm{CO}_{2}$ 测定装置も報告されてい $る^{13)}$.

\section{2 アンペロメトリー}

\section{1 電解電流測定法}

この方法には, 電極への加電厈一定に保つ定電位法 と, 電位を連続的に変化 (掃引)させる電位掃引法とが ある．連続測定といら観点からは前者, 高感度という点 からは後者がそれぞれ注目されるが，最近は後者む自動 化の方向にあり，その点で㻴境分析法として今後大い

*1すなわ古測定セルの参照側と測定側の酸素分圧が等しくな る. 
に期待できよう。

電位掃引法は，印加電圧の波形および単掃引か多重掃 引かなどによって幾つかに分類できる゙ ${ }^{(4)}$ が，のこぎり 波電圧を単掃引するストリッピング法 ${ }^{15)}$ が現在一般的 である。

ポーラログラフ法等の従来法との大きな相違は, 前段 濃縮過程 (前電解) を伴う点であり，これが高感度の理 由でもある.すなわち，つり下げ水銀滴電極や水銀义ッ キ白金電極あるいはグラッシーカーボン電極などの作用 電極を用いて，試料溶液中の目的イオンを定電位電解佂 より電極表面江電着濃縮（前電解）し，次作用電極の 電位を溶出電位（正電位）方向に一定速度で掃引して電 極上の金属を遂次酸化溶出させる，その際の電流電位曲 線を記録し，得られた曲線のピーク高さもしくはピーク 面積より目的イオンを定量する。

Lieberman ら ${ }^{16)}$ は，管状の水銀メッキグラファイト 電極を用いる流動系のストリッピング法を開発した．図 4 に流路図と電極構造を示す。まず，グラファイト管状
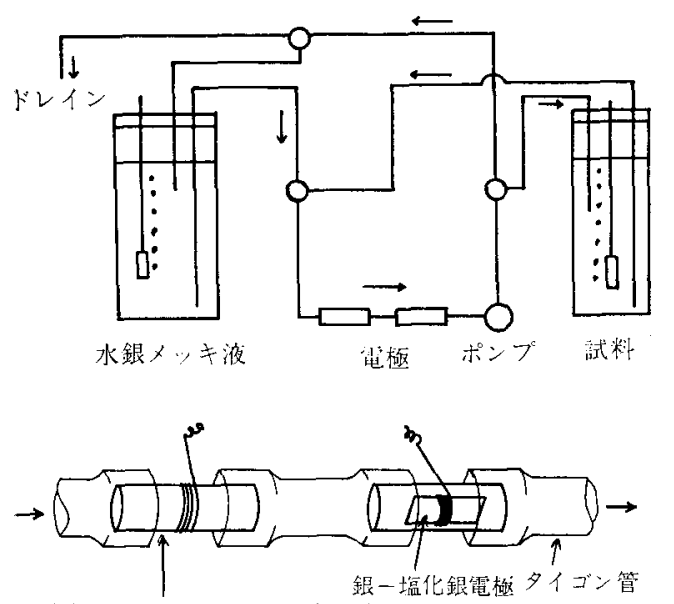

水銀メッキグラファイ! 管状電極

図 4 流動系ストリッピング法の流路図と電極構造

電極の電位を $-1.4 \mathrm{~V}$ (対銀-塩化銀参照電極) に保ち, その電極内部に水銀メッキ液定一定流速で 5 分間流寸.

次に流路を切り換え，金属イオンを含む試料溶液を流 して前電解する. 一定時間後, 電位を正方向へ掃引しこ のときの電流電位曲線を記録する，子たたび流路を切り 換えて水銀メッキ淮を流し，水銀薄膜の電着，試料の流 通, 前電解, ストリッピングの各操作をくり返す。この 装置を用いて海水中の $3 \times 10^{-8} \mathrm{M}$ 要鉛を相対標淮偏差 $\pm 9.5 \%$ の再現性で定量した，その電流電位曲線の一例 を図5に示市。

ストリッピング法の久点は, 電位掃引にともなって電 極表面の電気二重層による充電電流のため, 図 5 に見ら れるようにバックグラウンドが変化(傾斜) することで

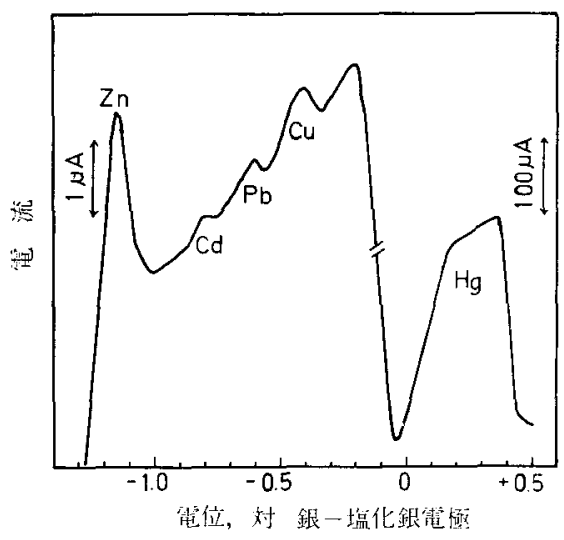

図 5 サンジエゴ湾海水の電流電位曲楾 ${ }^{16}$

ある.このためピーク電流の測定が困難になることがあ る. Blaedel ら $5^{173}$ 法，この久点補うため，前電解打 よびストリッピング用の円筒電極上，溶出した金属イオ ンを再析出させる円筒電極（捕集電極）とを連結した捕 集アノーディックストリッピング法*2,18 を報告してい る、この力法で泣，定電位の捕集電極を前電解およびス トリッピング用電極の下流に配置し，溶出してきた金属 イオンをこの電極で逐次電解してそのときの電解電流よ り定量する。したがって検出定羁淀電位の捕集電極で 行なわれるため，ストリッピング法の上うに充電電流に

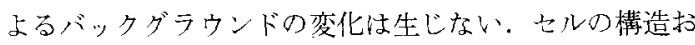
よび電解電流曲線をそれぞれ図 6 , 図 7 に示寸. 図7で

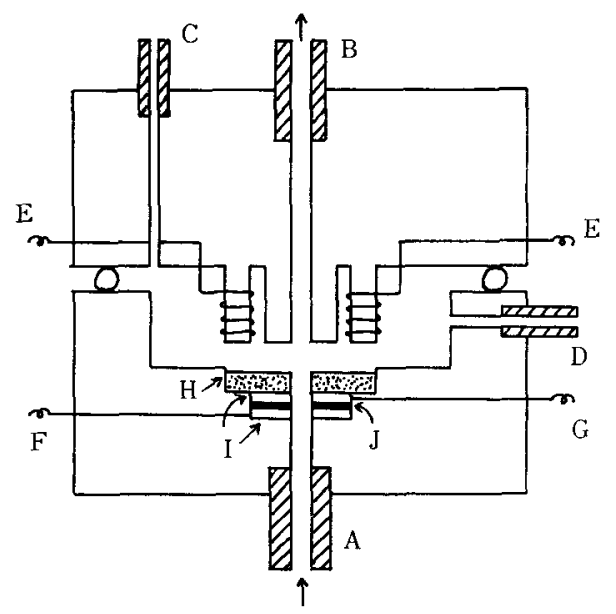

図 6 ASVWC 用電極セル

$\mathrm{A}$ : 試料入口, $\mathrm{B}$ : 試料出口, $\mathrm{C}$ : 参照電極液 $(0.1 \mathrm{M} \mathrm{KCl})$ 入口, $\mathrm{D}$ : 参照電極液出口, $\mathrm{E}:$ 参照電極 (銀-塩化銀電極) リード線， F：前電解およびストリッビング電極りード線, $\mathrm{G}$ : 捕集電極りード線, $\mathrm{H}$ : 陽イオン交換膜, I : グラッシ 一カーボン円筒電極，J：テフロンスペーサー

*2 Anodic stripping Voltammetry with Collection (ASVWC) 


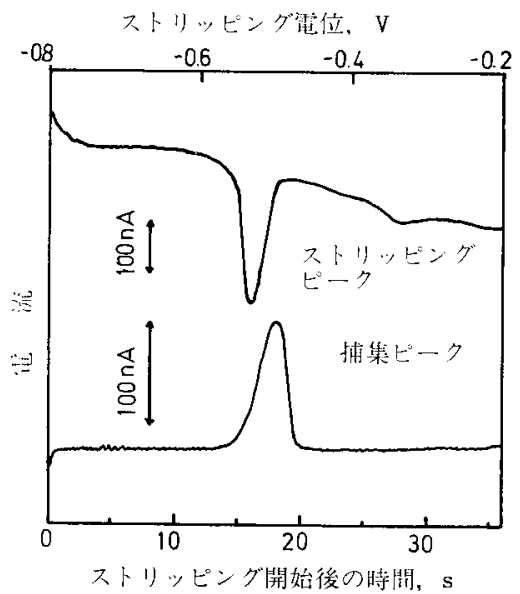

図 7 ASVWC のストリッピングおよび捕集ピーク

試料: $1 \times 10^{-7} \mathrm{M}$ 鉛, 電解液: $0.1 \mathrm{M}$ 塩酸

捕集電極電位 : $-0.80 \mathrm{~V}$, 電解液流速 $: 3.42 \mathrm{~cm}^{8} / \mathrm{min}$

上側の曲線はストリッピング電極によるものであり，比 較のために併記した．捕集ピーク電流 $i_{\mathrm{p} . \mathrm{c}}$ は，ストリ ッピング電流 $i_{\mathrm{p} . \mathrm{s}}$ に比例するはずであるから, 次の上 らに表わすことができる。

$$
i_{\mathbf{p} . \mathbf{c}}=-N i_{\mathbf{p}, \mathbf{s}}
$$

ここで、比例定数 $N$ は捕集効率である。

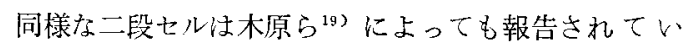
るがこれ後に述べるクーロメトリーに属する,

定電位電解電流测定法の中で注目されるのは, ガス拡 散電極 ${ }^{2)}$ を用いる大気測定装置である。このセルは三 電極より成り, 各電極はテフロンで覆れ, 電解液には $3.4 \mathrm{M}$ 硫酸が用いられている。この装置を用いて $\mathrm{NO}_{2}$ を測定寸るときには, 電極電位を $0.8 \mathrm{~V}$ (刘標準水素電 極) に設定し，

$$
\mathrm{NO}_{2} \cdot 2 \mathrm{H}^{+}+2 \mathrm{e} \longrightarrow \mathrm{NO}+\mathrm{H}_{2} \mathrm{O}
$$

に上って流れる還元電流 ( $-12 \mu \mathrm{A} / \mathrm{ppm} \mathrm{NO}$ ) を測定 し, これより $\mathrm{NO}_{2}$ 濃度定量する ${ }^{21)}$ 。地, $\mathrm{NO}$ 测定
のときには電極電位を $1.5 \mathrm{~V}$ に設定すると,

$$
\mathrm{NO}+2 \mathrm{H}_{2} \mathrm{O} \longrightarrow \mathrm{NO}_{3}{ }^{-}+4 \mathrm{H}^{+}+3 \mathrm{e}
$$

に従ってNO注迅速に酸化され，之の酸化電流(11 $\mu \mathrm{A}$ / ppm NO) より定量する211. たぶし，NO 測定のときに は $\mathrm{NO}_{2}$ も酸化されるたあ,トリエタノールアミンによ ってあらかじめ $\mathrm{NO}_{2}$ を定量的に除去しておく．他のガ ス成分による影響を 表 1 にまとめた。 また同じセルを 用いて $\mathrm{CO}$ の測定も行われた ${ }^{22)}$ 。なわち電極電位を $1.2 \mathrm{~V}$ に設定し,

$$
\mathrm{CO}+\mathrm{H}_{2} \mathrm{O} \longrightarrow \mathrm{CO}_{2}+2 \mathrm{H}^{+}+2 \mathrm{e}
$$

によって流れる酸化電流より，21〜385 ppm CO を士 I \%の再現性で定量した。

\section{2 ガルバニセル}

従来より溶存酸素の測定に多種のガルバニセルが開 発233,24)されており, そのセ儿構造もほぼ類似してい る.また, これらのセルは, 電解液や電極材質を変える ことにより, その他のガス成分（塩素, オン゙ン, 二酸化 炭素など) にも適用できる場合が多い。この種の七ルに ついては解説1をを参照していただくことにし，ここでは それ以外のガルバニセルについて紹介する。

Allen ${ }^{25}$ は, 白金網カソード, 活性炭ペーストケノー ド, 塩化カリウムよリン酸緩衝液 $(\mathrm{pH} 7)$ より成る電解 液、などから構成されたガルバ二セルを作り， $\mathrm{NO}_{2}$ の 絶対定量を行なった。七ルの構造を図 8 に示す.アノ 一ドとカソードは燒結ガラス板で仕切られている，カy ードにはガラス繊維製のろ紙が巻きつけてあり, 電解液 吸い上げてカソードを電解液の薄膜で常に湿らせるよ うにしてある.このセルで注カソードで,

$$
\mathrm{NO}_{2}+\mathrm{e} \longrightarrow \mathrm{NO}_{2}^{-}
$$

もしくは,

$$
\mathrm{NO}_{2}+\mathrm{H}^{+}+\mathrm{e} \longrightarrow \mathrm{HNO}_{2}
$$

\begin{tabular}{|c|c|c|c|c|}
\hline 成 & 濃澕 ppm & NO 測定時* ppm & 濃度 ppm & $\mathrm{NO}_{2}$ 測定時** $\mathrm{ppm}$ \\
\hline $\mathrm{SO}_{2}$ & 2150 & 影響なん & 20 & 影響なし \\
\hline NO & - & - & 466 & 影響なし \\
\hline $\mathrm{NO}_{2}$ & 25 & 影饗なし & - & - \\
\hline $\mathrm{CO}$ & 900 & 3,000 & 900 & 1000 \\
\hline 硝酸 $n$ nープロピル & $2.6 \times 10^{4}$ & $>2 \times 10^{5}$ & $2.6 \times 10^{4}$ & $>2 \times 10^{5}$ \\
\hline ニトロメタン & $4.0 \times 10^{4}$ & $>2 \times 10^{5}$ & $4.0 \times 10^{4}$ & $>2 \times 10^{5}$ \\
\hline Tニリン & 520 & 30,000 & 520 & 影響なし \\
\hline フンモニ & 7300 & 影響なし & 7300 & 影響なし \\
\hline ニトロベンゼン & 290 & 影響なし & 290 & 影響なし \\
\hline
\end{tabular}

の還元反応が起ると報告している． $\mathrm{NO}_{2}$ を含む試料が スの流速が $50 \mathrm{~cm}^{3} / \mathrm{min}$ 以下のときには，乙の反応はほ ぼ 100\%の効率で進行し，そのとき流れる電流は次式で

表 $1 \mathrm{NO}$ および $\mathrm{NO}_{2}$ 測定に扔ける他成分の影響

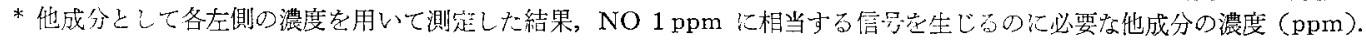

**同㥞に, $\mathrm{NO}_{2} 1 \mathrm{ppm}$ 沉相当する信号を生じるのに必要な濃度 $(\mathrm{ppm})$. 


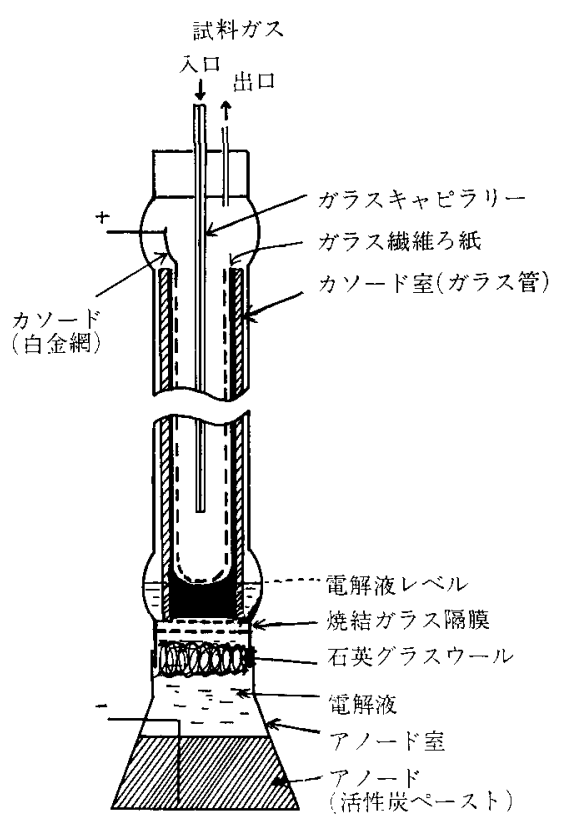

図 8 ガルバニセル

示される。

$$
i=0.0669 \times f_{i}
$$

ここで $f$ は， $20^{\circ} \mathrm{C}, 1$ 気王における試料ガスの流速， $c$ は $\mathrm{NO}_{2}$ の濃度 (ppm) である. 実験の結果, 流速が $50 \mathrm{~cm}^{3} / \mathrm{min}$ 以下, $\mathrm{NO}_{2}$ 濃度が $60 \mathrm{ppm}$ 以下の条件下で は上式より $\mathrm{NO}_{2}$ の絶対定量が可能であった。このセル による $\mathrm{NO}_{2}$ の検出下限は $0.001 \mathrm{ppm}$ である。この方 法の久点汪選抧性に乏しいことであり，才ジン， $\mathrm{SO}_{2}$,

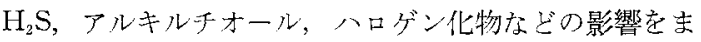
ともに受けるのでこれらはあらかじめ除去しておかな くてはならない。

\section{3 クーロメトリー}

クーロメトリーは電解セル中の注目成分を定量的に電 解し，それに要した電気暴(クーロン量)より定量する 方法であるが，これまでの電解セルではその構造上定量 的な電解を行ならのに長時間（数十分加ら数時間）を要 し，迅速性，連続性の点で大きな障壁よなっていた。

電解の速さ注次式のス（減衰定数， $\mathrm{S}^{-1}$ ) を目安とす ることができる゙26.

$$
\lambda=\frac{D A}{\delta V}
$$

ここで， $D$ 注注目成分の执散係数，A $A$ 作用電極の表 面積， $\delta$ は挔散層の厚さ，Vは電解液量である。したが って，作用電極表面積を可能な限り大省くするととも に，たとえば流動系にしてるを小さくし，また電解セル の溶液空げき(電解液量)を微小にすることによって,
入を大きくすることができる．

この考えに基づいて考案されたのが，微粒状もしくは 緎維状の電極（作用電極）を電極室に充てんしたカラム 電極 ${ }^{27}$ である.この種のカラム電極では，入值として $1 \mathrm{~S}^{-1, * 3}$ が得られている

木及ら ${ }^{193}$ は，図 9 に示すような定電位カラム電極を

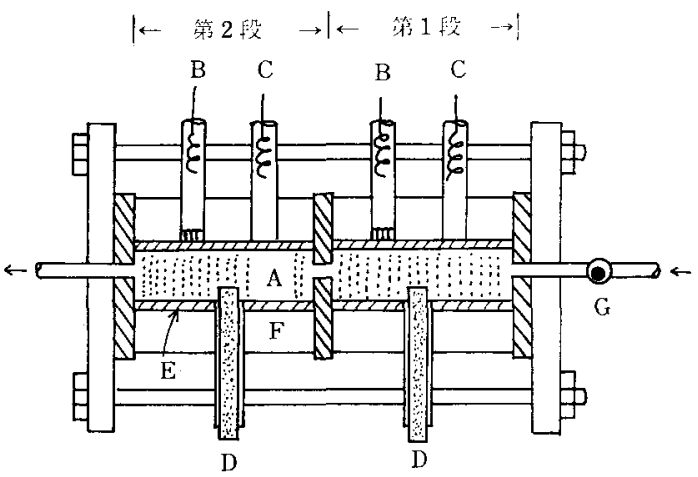

図 9 二段階フローターロメトリー電解セル

$\mathrm{A}$ ：作用電極（カーボン絨維）， B ：参照電極， C : 刘極 $\mathrm{D} ：$ 作用電極りード (グラッシーカーボン棒)， E：多孔 質ガラス管，F：刘極液，G：試料注入口

2 本值列に連結した二段階フローターロメトリーを考案 した。第一段およで第二段のセルの電極電位を -1.400 $\mathrm{V}$ (対硫酸第一水銀参照電極) に保ら, 力ドミウム, 鉛, 銅より成る試料溶液を流して第一段の電極に電解濃縮さ せる. 続いてこの電極電位女， $-1.000 \mathrm{~V},-0.500 \mathrm{~V}$, $+0.200 \mathrm{~V}$ と段階的に順次正方向一移動吉ることによ り，カドミウム，鉛，銅がそれぞれ分離溶出する。溶出 した各イオンは第二段の電極に流入し：ここで定電位電 解され，その際得られる電解電流の積分 值 (クーロン

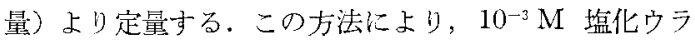
ニル中の各 $2 \times 10^{-7} \mathrm{M}$ のカドミウム, 鉓, 銅が分離定 量できた.

藤永 ${ }^{28), 29)}$ らは，一本のカラム電極に電位こう配老与 えたこら配電位規制方式のカラム電極製作し，これを 用いて電解クロマトグラフィー (Electrolytic Chromatography）上名ぶけた新しい電解分離法等開した。こ のカラム電極は，図 10 に示与上うに多孔質ガラス管に グラッシーカーボン粒 $(60 \sim 100$ メッシュ) を充てんし た作用電極部，銀線を巻いた対極部，および銀一塩化銀 参照電極部より構成されている．作用電極部の全長注約 $15 \mathrm{~cm}$ あり，上下間の内部抵抗注約 $100 \Omega$ に達する. この抵抗を利用して図のようにポテンショメーターを用 いてカラムの上下間に電位こう配を与える。ポテンショ

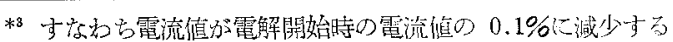
のに約 10 秒しかか心らない。 


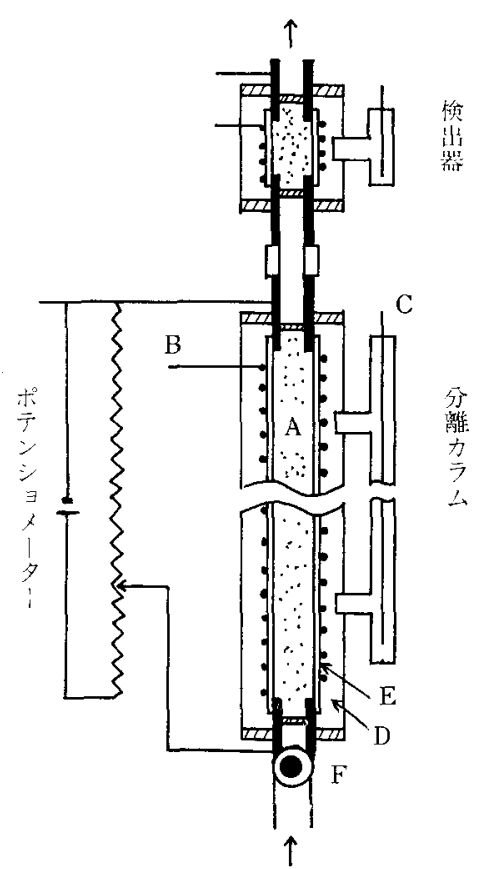

図 10 こう配電位規制方式力ラム電極

$\mathrm{A}$ ：作用電極 (グラッシーカーボン精), B : 対㥛 (銀線)

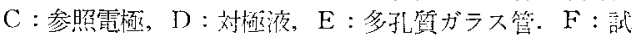
粼注入口

メーターおよびポテンショスタットによってカラムの上 端就よび下端の電位を適当に調節すれば，カラム入口よ り流入する金属イオンは，カラム内でおのおのの析出電 位に相忘する位置（作用電極上）に分離析出寸る．分離 後，力ラム電位を金属の溶出電位に設定してカラムより 順次溶出させる，溶出した成分は，出口に直結した定電 位カラム電極 (検出電極) によってクーロメトリックに 定量する。

電位こう配の代りに三角波電位を作用電極に多重掃引 して金属イオン在連続的に分離するカラム電解法も試み られている ため，電極活性物質の電極反応における可逆度の相違が 利用でき, 銅一ビスマス系など, 彷来, 電気化学的分離 の困難であった系にも適用されだ1).

その他力ラム電極は, 溶存酸素の定量 ${ }^{22}$, 液体ク口マ トグラフの検出器 ${ }^{33}$ などに虑用されている.

\section{4 その他の測定法}

ここでは, 上記の分類に含めにくいものにつけてまよ めるとともに，現在のところまだ環境計測に応用されて はいないが, 選択性, 特暴性, 感度等の点で今後の発展 が見込まれる測定素子について，Zのいくつかを簡単に 紹介する。
電界效果トランジスター (Field Effect Transister)の 中特に MOS (Metal Oxide Semiconductor) トランジ スターを用いる半導体センサー ${ }^{34)}$ は, 微小化, 多機能 化が可能な点で広い用途索持ち得る. MOS トランジス ターは，電流通路となる半導体表面の反転層（チャンネ ル)，チャンネル中にキャリア学流大する電極(ソース）, チャンネルからキャリアが流れ出してくる電極(ドレイ ン)，半導体表面上に被膜した絶縁膜（通常 $\mathrm{SiO}_{2}$ )，お よびこれに密着させた電極（グート）より構成されてい $\Xi^{35)}$. Moss ら ${ }^{36)}$ は, 金属ゲート電極の代りにカリウム イオンに選択性を持つバリノマイシン一可塑剤一ポリ塩化 ビニルより成る膜被膜し，銀一塩化銀参照電極在用い てカリウムイオン濃度 (活量) の测定を行なった。この 装置では，参照電極に+0.100 からち0.500 V のダート バイアス電圧を印加し，ソースよりドレインへ向ら電流 (ドレイン電流)を記録している.ドレイン電流はカリ ウムイオンの活量に比例するので，その電流值よりカリ ウムイオン濃度を測定することができる。この方法で， $10^{-4} \mathrm{M}$ のカリウムイオンが定量でき，また $10^{2} \sim 10^{3}$ 倍 のナトリウムイオン共存下でも測定可能であった。他に 水素分子の定量 ${ }^{37}$ について子研究されている.

圧電素子学用いて，ガス流中の目的成分在選択的に定 量する方法も報告されている。この方法ごは，吸着殽を 塗布した皮晶発振子を2枚の電極板ではさみ，一定の振 動数で振動させる。この測定セル汇試料ガスを通しる と, 目的成分が発振子上に吸着され, 次式に従ってその 振動数が変化する ${ }^{38}$.

$$
\Delta F=2.3 \times 10^{6} \times F^{2} \times \frac{\Delta W}{A}
$$

ここで，Fは水晶発振子の振動数，Aは発振子上の吸 着剤塗肪面積, そして $\Delta W か ゙$ 目的成分吸着後の塗布被膜 の重量（g）である. 通常， $9 \mathrm{MHz}$ の振動数が使用さ れ，電極には，金，ニッケル，銀，アルミニウムなどが 用いら机る. Guilbault らは種々の吸着剂を塗布して, $\mathrm{NO}_{2}{ }^{399}, \mathrm{SO}_{2}{ }^{40)}, \mathrm{NH}_{3}{ }^{41)}, \mathrm{H}_{2} \mathrm{~S}^{41)}$ などを测定しており, この方法による検出下限は約 $10^{-12} \mathrm{~g}$ といわれている またガスクロマトグラフの検出器としてる認識されつつ ある

その他, 電子移動反応によって起る化学発光老利用し た電解化学発光 (Electrochemiluminescence) ${ }^{43)}$ ，グラ ッシーカーボン板などの表面を化学的に修飾し電極反応 に化学的, 立体的な特異性, 選抧性を付与する化学修飾 電極 (Chemical Modified Electrode) ${ }^{44)}$ な゙, 今後, 㻴 境計測への応用が期待される方洁がいくつかかる。

\section{おわりに}

環境計測の立場加ら電気化学的分析法について最近の 動向を紹介した。また，研究の実験空段階では，以わば 
理想化された条件下で測定が行なわれるのに反し，実用 段階で注，種々の妨害成分の影響をはじめとして，測定 素子の污れ，寿命，保守など，質的に若干異なる諸問題 が生起する。しだって, 試料のサンプリングから測 定,さらにはそのデータ処理までも含めたトータルな検 討, 研究が環境化学計測に恃要求されるが，そのことに ついては本稿では触れなかった。

\section{文 献}

1) 鈴木繁喬, 分析化学 23, 426 (1974).

2) Z. Galus, "Fundamentals of Electrochemical Analysis", (1976), Ellis Horwood.

3) 梅沢喜夫, 化学の領域 31, 20 (1977).

4) J. Koryta, Anal. Chim. Acta 91, 1 (1977).

5) E. Pungor, "Ion-Selective Electrodes", (1973), Akademiai Kiado, Budapest.

6) J. Růžička and E.H. Hansen, Anal. Chim. Acta 78, 145 (1975).

7) E.H. Hansen, A.K. Ghose and J. Rủžička, Analyst 102, 705 (1977).

8) M. Mascini, Anal. Chim. Acta 85, 287 (1976).

9) 南条道夫, 本婄 44, 694 (1976).

10) M.M. Fishman and H.F. Schiff, Anal. Chem. 48, $322 \mathrm{R}$ (1976).

11) L.D. Bowers and P.W. Carr, Anal. Chem. 48, 544 A (1976).

12) D.M. Haaland, Anal. Chem. 49, 1813 (1977).

13) M. Gauthier and A. Chamberland, J. Electrochem. Soc. 124, 1579 (1977).

14) 高村勉, 本誌 39, 445 (1971).

15）三輪智夫，水池教，ら゙えせき 1975，356,

16) S.H. Lieberman and A. Zirino, Anal. Chem. 46, 20 (1974).

17) G.W. Schieffer and W.J. Blaedel, Anal. Chem. 49, 49 (1977).

18) D.C. Johnson and R.E. Allen, Talanta 20, 305
(1973).

19）本原壮林，本島健次，藤永太一郎，分析化学 21, 883(1972).

20) J.M. Sedlak and K.F. Blurton, Talanta 23, 445 (1976).

21) J.M. Sediak and K.F. Blurton, Talanta 23, 811 (1976).

22) H.W. Bay, K.F. Blurton, J.M. Sedlak and A.M. Valentine, Anal. Chem. 46, 1837 (1974).

23) E.A. Ostrovidou, Zh. Analit. Khim. 26, 1928 (1971).

24) C.J. Koch and J. Kruuv, Anal. Chem. 44, 1258(1972).

25) J.D. Allen, Analyst 99, 765 (1974).

26) 藤永太一郎, 分析化学 17,651 (1968).

27）禾原壮林，分析化学 22, 1642 (1973).

28) T. Fujinaga, Pure Appl. Chem. 25, 709 (1971).

29) T. Fujinaga, K. Izutsu and S. Okazaki, Rev. Polarog. (Kyoto), 14, 164 (1967).

30）鈴木繁喬，富田豊，荒林峻，分析化学 25，815 (1976).

31）富田豊, 鈴木繁喬, 荒不睃, 分析化学 26, 466 (1977).

32) E.L. Eckfeldt and E.W. Shaffer, Jr., Anal. Chem. 36, 2008 (1964).

33) Y. Takata and G. Muto, Anal. Chem. 45, 1864(1973).

34) 菅野卓雄, 本誌 44, 436 (1976).

35) J.N. Zemel, Anal. Chem. 47, 255 A (1975).

36) S.D. Moss, J. Janata and C.C. Johnson, Anal. Chem. 47, 2238 (1975).

37) I. Lundstrom, S. Shivaraman, C. Svensson and L. Lundkvist, Appl. Phys. Lett. 26, 55 (1975).

38) W.H. King, Jr., Anal. Chem. 36, 1735 (1964).

39) K.H. Karmarkar and G.G. Guilbault, Anal. Chim. Acta 75, 111 (1975).

40) K.H. Karmarkar, L.M. Webber and G.G. Guilbault, Anal. Chim. Acta 81, 265 (1976).

41) L.M. Webber and G.G. Guilbault, Anal. Chim. Acta 93, 145 (1977).

42) J. Hlavay and G.G. Guilbault, Anal. Chem. 49, 1890 (1977).

43）板谷䔆悟, 外岛 忍, 化学の領域 31, 18, 35 (1977).

44) 藤平正道, 長 哲郎, 本誌 45, 270 (1977). 